\title{
Association between Blood Lead, Nutritional Status, and Risk Factors of Hypertension and Diabetes Mellitus: A Study in Female Traffic Police Officers in Yogyakarta
}

\author{
Toto Sudargo ${ }^{1^{*}}$, Banun Ma'rifah Fathsidni', Dea Farah Zakia ${ }^{1}$, Yuliana Novita \\ Rachmawati', Muhammad Hafizh Hariawan', Rahadyana Muslichah', \\ Rathi Paramastri ${ }^{1}$ \\ ${ }^{1}$ Department of Health Nutrition, Faculty of Medicine, Universitas Gadjah Mada, \\ Yogyakarta 55281
}

\begin{abstract}
The research aimed to investigate the association of nutritional status, blood lead level, and risk factors of hypertension and diabetes mellitus in female traffic police officers routinely exposed to lead in Yogyakarta, Indonesia. Fifty-four female traffic police officers aged 20-50 year old participated in this cross-sectional study. As risk factors of diabetes and hypertension, Body Mass Index (BMI) was calculated from height and weight data while percentage of body fat $(\% \mathrm{BF})$ was measured using Bioelectrical Impedance Analysis (BIA). Energy intake (EI) was assessed using 1x24-hour dietary recall. Atomic Absorption Spectrophotometer (AAS) method was conducted to measure blood lead (Pb$\mathrm{S})$. Blood pressure (BP) was measured using mercury sphygmomanometer while blood glucose (Glu) was measured in laboratory. Pearson's and Spearman Rank correlation test were performed for statistical analysis. We demonstrated that $\mathrm{Pb}-\mathrm{S}$ was positively correlated with both systolic and diastolic $\mathrm{BP}$ but not with BMI, \%BF, and Glu. Meanwhile, there was a correlation between Glu and either BMI or \%BF but not EI. Therefore, our study indicates that exposure to lead is correlated with hypertension while nutritional status is more correlated with diabetes mellitus.
\end{abstract}

Keywords: blood glucose, blood lead, female traffic police, hypertension, nutritional status

\section{INTRODUCTION}

Indonesia is among many countries with high levels of environmental pollution where unchecked industrial growth has led to an inevitable increase in air pollutants such as lead $(\mathrm{Pb})$. Lead exposure continues to be a tremendous international public health concern as it may predispose individuals of any age group to a wide range of health problems (Wani et al. 2015). Research has confirmed that exposure to lead may introduce acute and chronic effects on health outcomes (Pahlawan \& Keman 2014).

Lead enters the body mainly through the air, food, and water and accumulates short-term in blood (1 month) and long-term in bone (up to 20 years) (Wani et al. 2015). Centers for Diseases Control and Prevention (CDC) have suggested the threshold for blood lead level to be $10 \mu \mathrm{g} / \mathrm{dl}$. However, the harmful effects of lead toxicity are not limited to values beyond the aforementioned threshold since low levels of blood lead have been found to be associated with increased risk factor of all chronic illnesses, cardiovascular diseases, and cancer mortality (Menke et al. 2006).

Lead exposure is one of the established risks of cardiovascular diseases (CVD). Leadinduced CVD, alongside mental retardation, accounted for $1 \%$ of global burden of disease with the highest burden in the developing countries (Fewtrell et al. 2004). There is well-established evidence from meta-analysis studies where significant correlations between hypertension and level of lead accumulated in both blood and bone were found (Nawrot et al. 2002). However, the evidence is inconclusive for lead exposure below $5 \mu \mathrm{g} / \mathrm{dl}$ as previously found across different genders and races (Den Hond et al. 2002). Recently, a cohort study suggested that low levels of blood lead $(2.8 \mu \mathrm{g} / \mathrm{dl})$ independently increased blood pressure and risk of hypertension (Gambelunghe et al. 2016). It is clear that more research is still needed focusing on the effects of low exposure of lead.

In contrast to CVD, there is limited evidence where lead exposure is linked to an in-

"Corresponding Author: email: toto_sudargo@yahoo.co.id 
creased risk of diabetes mellitus. Previously, a cross-sectional study indicated an increase in fasting blood glucose among male workers with high blood lead levels (Bener et al. 2001). However, to date, there has been no further study conducted to elaborate on this topic. Meanwhile, lead is considered an Endocrine Disrupting Chemicals (EDC) which may compromise hormonal regulation in human's body. Glucocorticoids and insulin are among the hormones potentially affected by lead exposure. As a result, glucose uptake by cells diminishes and blood glucose raises (Casals-Casas \& Desvergne 2011). Thus, further study is worth-conducting to investigate whether lead toxicity may be a potential risk factor of diabetes mellitus.

In some big cities in Indonesia including Yogyakarta, one of the top contributors to air pollution is motor vehicles. Emissions from motor vehicles contributed to $85 \%$ of air pollutants and will potentially increase as the volume of vehicles on the road increases. Investigation in some locations indicated that motor vehicles contributed up to $98.8 \%, 73.4 \%, 88.9 \%$, and $100 \%$ of $\mathrm{CO}, \mathrm{NO}$, $\mathrm{HC}$, and lead, respectively, in the air (Pahlawan \& Keman 2014). In Yogyakarta, the levels of lead pollution in some locations with the highest volume of motor vehicles ranged from $1.05 \mathrm{mg} / \mathrm{Nm}^{3}$ to $1.56 \mathrm{mg} / \mathrm{Nm}^{3}$. Meanwhile, the recommended threshold for lead pollution according to the government law released in 2002 was $2 \mathrm{mg} / \mathrm{Nm}^{3}$. The level of lead pollution in Yogyakarta is a growing concern as the number of vehicles continues to increase.

Traffic police officers are among the atrisk populations routinely exposed to lead exposure due to their occupational environment. More specifically, based on a study in Europe, women aged 19-39 years was reported to face a 5-fold increase risk of metabolic syndrome by the age of 60-78 years which was greater compared to men (2-fold) (Vishram et al. 2014). Therefore, we conducted this study to determine the correlation between nutritional status measured as body mass index (BMI) and body fat percentage (\%BF), serum lead level $(\mathrm{Pb}-\mathrm{S})$, and parameters of cardio metabolic diseases including blood pressure (BP) and blood glucose concentration (Glu) in female traffic police officers in Yogyakarta, Indonesia.

\section{METHODS}

\section{Design, location, dan time}

This observational study was conducted with a cross-sectional design in Yogyakarta.
Study population was female traffic police from all five cities in the province including Yogyakarta City, Sleman, Kulon Progo, Bantul, and Gunung Kidul. Inclusion criteria were subjects must be 20-50 years old and actively working in road traffic with high volume of vehicles for at least 1 year. Exclusion criteria included having diagnosed with chronic or infection diseases, pregnant, and experienced post-menopausal phase. The research was done in May-July 2017. Sample size was calculated based on using Lameshow formula below which resulted in a minimum number of 51 subjects.

\section{Data collection}

Subjects completed anthropometric measurements including body weight and height as well as percentage of body weight (\%BF). A calibrated Bioelectric Impedance Analysis (BIA) was used to measure body weight and $\% \mathrm{BF}$ while height was measured using a microtoise. Body mass index (BMI) was then calculated based on body weight and height data. Subjects' nutritional status were determined based on the WHO BMI classification for Asian population.

Energy intake (EI) was assessed using 24-h dietary recall conducted by trained interviewer. A brief instruction and food model were provided. All foods and drinks consumed in the last 24 hours were reported including details of portion size, brands, and cooking process. Finally, additional probing for confirmation was performed to ensure the accuracy and completeness of foods reported. Population-based validated Nutrisurvey software was employed to estimate subjects' energy intake.

Blood measurement included were lead and glucose concentrations. Serum blood lead level $(\mathrm{Pb}-\mathrm{S})$ was defined as the amount of lead accumulated in the blood circulation. Blood glucose measurement was conducted in the morning after 10 hour overnight fast. Approximately $5 \mathrm{ml}$ of venous blood was taken from the subjects elbow pit (fossa cubiti) using a syringe by an experienced phlebotomist. Atomic Absorption Spectroscopy (AAS) method was conducted to measure blood lead levels while blood glucose concentration was measured in the laboratory using spectrophotometry kit.

Systolic (SBP) and diastolic (DBP) blood pressures were measured using a calibrated mercury sphygmomanometer with inflatable cuff for adults by trained researchers. A stethoscope was placed on the brachial artery of participant's right upper arm. Subjects were asked to rest for 
5 minutes before having their blood pressure taken. While doing the measurement, subjects must remain silent, relaxed, and seated with their back supported and legs uncrossed. For accuracy, measurements were duplicated with an appropriate interval and average values were taken for the analysis.

Data collection instruments including BIA, sphygmomanometer, and AAS test kit were calibrated. All procedures throughout this study were conducted based on the Declaration of Helsinki. This study was approved by the Ethics Committee of Faculty of Medicine, Universitas Gadjah Mada (KE/FK/0338/EC/2017). Signed informed consent forms were obtained from all subjects before the commencement of this study.

\section{Data analysis}

Data collected was initially cleaned for any outliers before being analyzed using IBM SPSS 21 Software. Shapiro-Wilk test was employed to analyze the normality of data. Correlation Test was employed depending on the distribution of variables to analyze the association between BMI and $\mathrm{Pb}-\mathrm{S}$, EI and $\mathrm{Pb}-\mathrm{S}, \mathrm{BMI}$ and Glu, \%BF and $\mathrm{Glu}, \mathrm{Pb}-\mathrm{S}$ and $\mathrm{BP}$ as well as $\mathrm{Pb}-\mathrm{S}$ and Glu.

\section{RESULTS AND DISCUSSION}

Fifty-four female traffic police officers from five cities in the Province of Yogyakarta participated in our study with details as follow; Yogyakarta City $(\mathrm{n}=21)$, Sleman $(\mathrm{n}=11)$, Kulon Progo $(n=7)$, Gunung Kidul $(n=5)$, and Bantul $(n=10)$. Characteristics of subjects are presented in Table 1. Mean BMI was classified as overweight $(24.6 \mathrm{~kg} / \mathrm{m} 2)$ while mean percentage of body fat was slightly below the cut-off point for excess fat. Dietary intake of subjects was low, meeting only half of the Recommended Dietary Allowance (RDA). The average blood lead level of subjects in our study was $0.05 \mu \mathrm{g} / \mathrm{dL}$. This value is considered low as it is below the threshold value $(10 \mu \mathrm{g} / \mathrm{dl})$. Mean systolic/diastolic blood pressure $(114.1 / 75.6 \mathrm{mmHg})$ and blood glucose concentration was $90.8(\mathrm{mg} / \mathrm{dl})$ which fell into the normal range.

Shapiro-Wilk normality test indicated that only $\%$ BF data was normally distributed. Hence, Spearman's Rank Correlation Test was chosen to analyze the association between $\mathrm{Pb}-\mathrm{S}$ and either BMI, \%BF, Glu, and BP (Table 2). Increase in $\mathrm{Pb}-\mathrm{S}$ is associated with elevation in systolic $(\mathrm{r}=0.28)$ and diastolic BP $(0.42)(\mathrm{p}<0.05)$ although the correlation was weak. Previously, it was suggested that 2-fold concentration of blood
Table 1. Characteristics of participants

\begin{tabular}{lc}
\hline \multicolumn{1}{c}{ Variable } & Mean $\pm \mathrm{SD}$ \\
\hline Age $($ year) & $31.79 \pm 7.39$ \\
BMI $\left(\mathrm{kg} / \mathrm{m}^{2}\right)$ & $24.64 \pm 3.30$ \\
Body Fat $(\%)$ & $31.92 \pm 3.76$ \\
Energy intake $(\% \mathrm{RDA})$ & $50.43 \pm 17.1$ \\
Blood lead level $(\mu \mathrm{g} / \mathrm{dl})$ & $0.05 \pm 0.10$ \\
Blood glucose $(\mathrm{mg} / \mathrm{dl})$ & $90.85 \pm 19.18$ \\
Systolic blood pressure $(\mathrm{mmHg})$ & $114.1 \pm 11.92$ \\
Diastolic blood pressure $(\mathrm{mmHg})$ & $75.6 \pm 9.56$ \\
\hline
\end{tabular}

lead might be associated with an increase in systolic and diastolic blood pressure by $1.45 \mathrm{mmHg}$ and $1.25 \mathrm{mmHg}$, respectively. Correlation with systolic blood pressure was also indicated when lead concentration was measured from the bone which has longer half-life in the human body. Thus, it may be inferred from this study that lead exposure that happened in the past few months might still be associated with hypertension. Our finding is also similar with finding from an observational study by Deyot involving parking staff along Malioboro Street in Yogyakarta where blood lead levels were significantly correlated with incidence of hypertension $(\mathrm{r}=0.22 ; \mathrm{p}<0.05)$ (Deyot 2013). In this study, $72.7 \%$ subjects with hypertension had blood lead concentrations beyond the threshold value $(10 \mu \mathrm{g} / \mathrm{dl})$ while the average concentration of blood lead in our study was far below the threshold $(0.05 \mu \mathrm{g} / \mathrm{dl})$. Thus, our finding may add to the evidence that even a low level of blood lead can be associated with an elevation in both systolic and diastolic blood pressure.

Blood glucose concentration was weakly associated with blood lead level $(\mathrm{r}=0.06)$ which was not statistically significant $(\mathrm{p}=0.64)$ (Table 2 ). This result was in contrast with a previous cross-over study by Bener and colleagues where they demonstrated a significant correlation between blood lead level and fasting blood glucose $(\mathrm{r}=0.4 ; \mathrm{p}<0.01)($ Bener et al. 2001). However, it is noteworthy that subjects' average blood lead level in our study $(0.05 \mu \mathrm{g} / \mathrm{l})$ was categorized as normal far below the cut-off for lead toxicity (US Department of Health and Human Services 2007). Additionally, our study involved a smaller sample size $(n=54)$ compared to the previous study (110 workers and 110 non-workers) (Bener et al. 2001). Therefore, it may be concluded that the low level of blood lead as well as small sample size in our study may not be sufficient to generate association with blood glucose concentration. 


\section{Sudargo et al.}

Table 2. Correlation between blood lead $(\mathrm{Pb}-\mathrm{S})$, body mass index (BMI), percentage body fat $(\% \mathrm{BF})$, energy intake (EI), fasting blood glucose (Glu) and blood pressure (BP)

\begin{tabular}{cccccccc}
\hline \multirow{2}{*}{ Variables } & \multicolumn{2}{c}{ Systolic Blood Pressure } & \multicolumn{2}{c}{ Diastolic Blood Pressure } & \multicolumn{2}{c}{ Glu } \\
\cline { 2 - 7 } & $\mathrm{r}$ & $\mathrm{p}$ & $\mathrm{r}$ & $\mathrm{p}$ & $\mathrm{r}$ & $\mathrm{p}$ \\
\hline $\mathrm{Pb}-\mathrm{S}$ & 0.28 & $0.043^{*}$ & 0.42 & $0.002^{*}$ & 0.06 & 0.64 \\
$\mathrm{BMI}$ & 0.28 & $0.038^{*}$ & 0.29 & $0.031^{*}$ & 0.28 & $0.037^{*}$ \\
\%BF & 0.29 & $0.036^{*}$ & 0.32 & $0.020^{*}$ & 0.30 & $0.026^{*}$ \\
$\mathrm{EI}$ & -0.17 & 0.22 & -0.10 & 0.47 & -0.12 & 0.41 \\
\hline
\end{tabular}

*significant in $p<0.05$

Blood glucose, however, was significantly associated with both BMI $(\mathrm{r}=0.28)$ and $\% \mathrm{BF}$ $(\mathrm{r}=0.30)(\mathrm{p}<0.05)($ Table 2$)$. It was indicated that subjects having a higher BMI or percentage of body fat were more likely to be linked with higher fasting blood glucose concentration. Thus, instead of blood lead level, nutritional status seemed to be a more potential factor correlated with blood glucose concentration. These findings may support the current evidence where obesity is one of the predominant risk factors of type-2 diabetes mellitus (Nguyen et al. 2011; Bell et al. 2014).

Our study indicated that blood lead level was neither associated with BMI $(\mathrm{r}=-0.1 ; \mathrm{p}=0.47)$ nor $\% \mathrm{BF}(\mathrm{r}=-0.13 ; \mathrm{p}=0.33)$ (Table 2$)$. These results confirmed the findings from a previous investigation in female traffic police officers in Semarang Barat, Indonesia where no correlation between nutritional status and blood lead level was found (Mahawati 2011). In another study, Ronco and colleagues also found no significant correlation between blood lead level and both BMI and body fat percentage. In addition, this study also could not reveal the role of BMI or body composition in the regulation of lead toxicity (Ronco et al. 2010). Our finding, however, was in contrast with a previous study by Rustanti and Mahawati involving public transportation drivers where a significant negative correlation was indicated between blood lead level and BMI $(r=-0.38 ; p<0.05)$ (Rustanti \& Mahawati 2011). In another research, Riedt and associates found that lower body weight and thus BMI was correlated with higher blood lead level after 6 months of cohort study (Riedt et al. 2009). This difference might be due to the longer period of lead exposure and higher blood lead concentration of subjects in the previous study. Therefore, the low level of blood lead in our study may not be sufficient to generate association with nutritional status.
As summarized in Table 2, this study demonstrated no significant association between energy intake and blood glucose concentration $(\mathrm{r}=-0.12 ; \mathrm{p}=0.41)$. Similarly, previous study also demonstrated that energy intake in total as well as carbohydrate intake alone were not correlated with blood glucose and body mass index (Refdanita et al. 2017). This non-significant correlation may be caused by several potential confounders such as physical activity level, stress level, and family history of chronic diseases which were not investigated in the present study. In addition, the use of 24-hour dietary recall as dietary assessment tool has several limitations. The Flat Slope Syndrome, for instance, might be one of the limitations as there is a tendency for subjects to under- or overestimate their dietary intake. It was also indicated that individuals with higher BMI were more likely to under-report their daily consumption (Flegal 1999). As the average BMI of our subjects was classified into overweight, it is likely that the amount of energy intake reported in our study was below the actual amount. Indeed, as reported, the average energy intake of our subjects was only half of the Recommended Dietary Allowance (RDA).

Our study results, however, were attributed to several limitations. As we adopted a crosssectional design, we were unable to determine any causal relationship. Additionally, although we have done sample calculation, our sample size was smaller compared to previous studies on this topic with similar study design. Furthermore, our statistical analysis did not adjust the correlation for any potential confounders such as physical activity level, age, sex, smoking habit, and family history of any chronic diseases. In terms of markers of lead exposure, we performed measurement of blood lead concentration. Blood lead might not provide an estimation of longterm lead exposure as it has a shorter half-life in 
the body. However, to date, blood lead is still the most feasible and reliable indicator of recent lead exposure. Dietary intake was assessed using only one tool which was the 24-hour dietary recall. As mentioned before, this method has some limitations and the additional use of 3-day food diary or FFQ as reference methods might provide a more accurate measurement. Furthermore, we did not observe whether different macronutrients intake were associated with our outcomes.

Meanwhile, there are several strengths of this study including using the measurement of percentage of body fat as a part of the anthropometric measurements. Body fat percentage has been suggested as a reference measurement of BMI measurement as it may distinguish the proportion of body fat from other body tissues. Thus, measuring body fat percentage along with BMI has been demonstrated to provide a better predictor for risk of cardio-metabolic diseases (Phillips et al. 2013).

\section{CONCLUSION}

The present study aimed to primarily observe the correlation between nutritional status, lead exposure, and markers of hypertension and diabetes mellitus in 54 female traffic police officers in Yogyakarta, Indonesia. Increased blood lead level was associated with elevated systolic and diastolic blood pressure but not with blood glucose, BMI, and body fat percentage. Meanwhile, higher blood glucose was associated with increase in BMI and body fat percentage. Our study indicates that exposure to lead is correlated with hypertension while nutritional status is more correlated with diabetes mellitus

\section{ACKNOWLEDGEMENTS}

The authors would like to thank the Faculty of Medicine and Universitas Gadjah Mada, Yogyakarta, for the support given throughout this study.

\section{REFERENCES}

Bell JA, Kivimaki M, Hamer M. 2014. Metabolically healthy obesity and risk of incident type 2 diabetes: a meta-analysis of prospective cohort studies. Obesity Reviews 15(6):504-515.

Bener A, Obineche E, Gillett M, Pasha MAH, Bishawi B. 2001. Association between blood levels of lead, blood pressure, and risk of diabetes and heart disease in workers. Int Arch Occup Environ Health 74(5):375-378.

Casals-Casas C, Desvergne B. 2011. Endocrine disruptors: from endocrine to metabolic disruption. Annual Review ods Physiology 73:135-162.

Den Hond E, Nawrot T, Staessen JA. 2002. The relationship between blood pressure and blood lead in NHANES III. Journal of Human Hypertension 16(8):563-568.

Deyot YK. 2013. Masa kerja, Kadar timbal darah, dan kejadian hipertensi pada petugas parkir di jalan malioboro Yogyakarta. [Tesis]. Yogyakarta: Universitas Gadjah Mada.

Fewtrell LJ, Pruss-Ustun A, Landrigan P, AyusoMateos JL. 2004. Estimating the global burden of disease of mental retardation and cardiovascular diseases from environmental lead exposure. Environmental Research 94(2):120-133.

Flegal KM. 1999. Evaluating epidemiologic evidence of the effects of food and nutrients exposures. Am J Clin Nutr 69(6):1339S$1344 \mathrm{~S}$.

Gambelunghe A, Sallsten G, Borne Y, Forsgard N, Hedblad B, Nilsson P, Fagerberg B, Engstrom G, Barreard L. 2016. Low level exposure to lead, blood pressure, and hypertension in a population-based cohort. Arct Environ Res 149:157-163.

Mahawati E. 2011. Faktor-faktor resiko paparan $\mathrm{Pb}-\mathrm{B}$ pada polisi lalu lintas di Semarang Barat. Jurnal Visikes 10(2).

Menke A, Muntner P, Batuman V, Silbergeld EK, Guallar E. 2006. Blood lead below 0.48 $\mathrm{mcromol} / \mathrm{l}(10 \mathrm{microg} / \mathrm{dl})$ and mortality among US adults. Circulation 114(13): 1388-1394.

Nawrot TS, Thijs L, Den Hond EM, Roels HA, Staessen JA. 2002. An epidemiologican re-appraisal of the association between blood pressure and blood lead: a metaanalysis. J Hum Hyperens 16(2):123-131.

Nguyen NT, Nguyen XT, Lane J, Wang P. 2011. Relationship between obesity and diabetes in a US adult population: findings from the National health and nutrition examination survey, 1999-2006. Obes Surg 21(3):351355.

Pahlawan SD, Keman S. 2014. Korelasi kadar plumbun darah dengan kadar hemoglobin dan hematokrit. Jurnal Kesehatan Lingkungan 7(2):159-165. 
Phillips CM et al. 2013. Obesity and body fat classification in the metabolic syndrome: impact on cardiometabolic risk metabotype. Obesity 21(1):154-161.

Refdanita, Damayanthi E, Dwiriani CM, Sumantri C, Effendi AT. 2017. Hubungan karakteristik pria dewasa dengan Biomarker sindroma metabolik. J Gizi Pangan 12(2): 79-84.

Riedt CS, Buckley BT, Brolin RE, Ambia-Sobhan H, Rhoads GG, Shapses SA. 2009. Blood lead levels and bone turnover with weight reduction in women. J Expo Sci Environ Epidemiol 19(1):90-96.

Ronco AM, Gutierrez Y, Gras N, Munoz L, Salazar G, Llanos MN. 2010. Lead and arsenic levels in women with different body mass composition. Biological Trace Elements Research 136(3):269-278.

Rustanti I, Mahawati E. 2011. Faktor-faktor yang berhubungan dengan kadar timbal (Pb-B) dalam darah pada sopir angkutan umum jurusan Karawang Ayu-Penggaron di kota Semarang. Jurnal Visikes 10(1).

Vishram JKK et al. 2014. Impact of age and gender on the prevalence and prognostic importance of the metabolic syndrome and its components in europeans. The Morgam Prospective Cohort Project. Plos One 9(9).

Wani AL, Ara A, Usmani JA. 2015. Lead toxicity: a review. Interdiscip Toxicol 8(2):5564. 